\title{
Genetic Epidemiology and Heritability of Vitiligo
}

\author{
Abdullateef A. Alzolibani ${ }^{1}$, Ahmad Al Robaee ${ }^{1}$ \\ and Khaled Zedan ${ }^{2}$ \\ ${ }^{1}$ Department Of Dermatology, College Of Medicine, Qassim University \\ ${ }^{2}$ Pediatric Department, College Of Medicine, Qassim University \\ Saudi Arabia
}

\section{Introduction}

\subsection{Prevalence \& incidence}

The population prevalence of vitiligo ranges from $0.1 \%$ to $2 \%$ and shows a wide variability among ethnic groups (Bolognia et al., 1998; Hann and Nordlund, 2000). Whereas the estimated population prevalence of vitiligo is approximately $0.38 \%$ for Caucasians in the United States and Northern Europe (Howitz et al., 1977), vitiligo affects $0.19 \%$ of the population in China ( $\mathrm{Xu}$ et al., 2002). Other international studies show that the incidence of vitiligo ranges from 0.1 to over $8.8 \%$ (Srivastava, 1994; Schwartz and Janniger, 1997; Hann et al., 1997; Kovacs, 1998; Agarwal, 1998; Handa and Kaur, 1999; Alkhateeb et al., 2003). The highest incidence of the condition has been recorded in Indians from the Indian subcontinent, followed by Mexico and Japan (Table 1). The difference in its incidence may be due to higher reporting of vitiligo in a population, where an apparent color contrast and stigma attached to the condition may force patients to seek early consultation (Panja, 1947; Levai, 1958; Punshi and Thakre, 1969; Behl and Bhatia, 1971; Sehgal, 1974; Koranne and Sachdeva, 1988; El Mofty, 1968; Grunnet et al., 1970; Dawber, 1968; Perrot, 1973; Fornara, 1941; Canizares, 1960; Ruiz Maldonnado et al., 1977; Fitzpatrick, 1974; Arakawa, 1941; Khoo, 1962).

Vitiligo is reported more frequently in females than males, which may be the result of increased reporting rates in females due to greater social consequences in females affected by vitiligo (Kovacs, 1998; Lee Poole and Boissy, 1997; Hann and Lee, 1996; Zaima and Koga, 2002; Jeninger, 1993; Halder, 1997; Cho et al., 2000; Handa and Dogra, 2003).

Adults and children of both sexes are equally affected; however, the majority of the vitiligo cases are reported during stages of active development. About $50 \%$ of patients present before the age of 20 and nearly $70-80 \%$ present before 30 years of age. Although no age is immune to vitiligo, the disease is very rarely observed at birth (Behl et al., 2003; Jaigirdar et al., 2002; Engel, 2001; Lerner, 1999; Gauthier et al., 2003; Westerhof et al., 1996).

The proportion of patients with a positive family history varies from one part of the world to another, with particularly wide ranges reported in India (6.25-18\%), with reports of up to $40 \%$ elsewhere in the world (Behl et al., 2003). 


\begin{tabular}{lclc}
\hline \multicolumn{1}{c}{ Author(s) } & Year & \multicolumn{1}{c}{$\begin{array}{c}\text { City/or } \\
\text { Region/Country/Continent }\end{array}$} & Incidence (\%) \\
\hline El Mofty & & & \\
Panja & 1968 & Egypt/Africa & 1 \\
Levai & 1947 & Calcutta/India/Asia & 6 \\
Punshi \& Thakre & 1958 & Vellore/India/Asia & 4 \\
Behl \& Bhatia & 1969 & Amrawati/India/Asia & 8 \\
Sehgal & 1972 & Delhi/India/Asia & 8.8 \\
Koranne \&Sachdeva & 1974 & Goa/India/Asia & 2.9 \\
Howitz et al. & 1988 & Delhi/India/Asia & 1.25 \\
Grunnet et al. & 1977 & Denmark/Europe & 0.38 \\
Dawber & 1970 & Denmark/Europe & 1.44 \\
Perrot & 1968 & England/Europe & 0.15 \\
Fornara & 1973 & France/Europe & 3.0 \\
Canizares & 1941 & Italy/Europe & 0.3 \\
Ruiz-Maldonnado & 1960 & Mexico/North America & 4 \\
Fitzpatrick & 1977 & Mexico/North America & 2.6 \\
& 1974 & Massachusetts/United & 8 \\
Arakawa & & States/North America & 1.64 \\
& 1941 & Japan/Asia & 0.7 \\
Khoo & & & \\
& 1962 & Malaysia/Asia & \\
\hline & & & \\
\hline
\end{tabular}

Table 1. Vitiligo: Global Incidence Patterns

\section{Epidemiology of vitiligo: A worldwide survey}

Numerous studies have been conducted around the world concerning the epidemiological characteristics of vitiligo, in particular the racial, ethnic, and cultural differences in its prevalence.

\subsection{Europe}

\subsubsection{Denmark}

The prevalence of vitiligo was $0.38 \%$ in a representative population of 47,033 in Denmark. Both sexes were found to be equally affected, with no significant difference found in the distribution of vitiligo patients among five different municipalities or between urban and rural districts. New cases of vitiligo steadily increased with advancing age, its onset being most often between the ages of 40 and 60 years of age. The age-specific prevalence increased from $0.09 \%$ in patients under the age of 10 to $0.9 \%$ in the age group between 60 to 69 years. It was suggested that these characteristics of vitiligo in Denmark would also apply to northwest Europe (Howitz et al., 1977). 


\subsubsection{United Kingdom}

The characteristics of vitiligo in 41 adults presenting to a university dermatology clinic in Sheffield, United Kingdom were studied in a case review. Of 41 patients, there were 29 women $(70.7 \%)$ and 12 men (29.3). The authors reported an age of onset before 20 years in $41.5 \%$ of patients $(n=17)$, while the mean was 28 years. The oldest age of onset was 74 years. In these patients, the average duration of disease was 16 years. Autoimmune thyroid disease was present in $34.1 \%$ of cases $(n=14)$. Only $17 \%(n=7)$ gave a family history of vitiligo (Mason and Gawk Rodger, 2005).

\subsection{Middle East}

\subsubsection{Saudi Arabia: Qassim region}

Alzolibani found that in a random sampling of vitiligo patients in the Qassim region of Saudi Arabia, approximately one-third of cases were positive for parental consan 'guinity.

A particularly high first-cousin consanguinity was noted in this study, which was found to be higher than that reported among the general Saudi population (22.5\% vs. 19.5\%) (Alzolibani, 2009; El-Hazmi et al., 1995).

Moreover, a positive family history was obtained in $56.8 \%$ of families studied, $57.1 \%$ of them having two or more affected relatives. The age of onset of vitiligo was 31 years in familial cases and 33 years in non-familial controls. Vitiligo occurred before the age of 20 in $19 \%$ of family cases and in $36 \%$ of non-familial controls. Most families (75\%) had no more than two affected members.

As observed in this study, the incidence rate of vitiligo in relatives increased with a closer blood relationship to probands, which is indicative of the significant familial aggregation of vitiligo noted in a number of previous studies (Nath et al., 1994; Majumder et al., 1988). The proband cases in this study showed higher relative risks among their first- and seconddegree relatives, but not as high among their third-degree relatives.

Inheritance pattern prediction using the frequency of vitiligo among siblings in relation to the general population coincided with the multifactorial model particularly for the vitiligo vulgaris subtype followed by the acrofacial subtype, and least in the focal subtype. Calculation of heritability showed a high weighted mean of 0.54 .

Similar data from China supports these findings (Sun et al., 2006).

Genetic factors play a relatively important role in the evolution of vitiligo among subjects in the Qassim region. Recognition of this could have a potential impact on disease prevention through family counseling and other forms of intervention.

\subsubsection{Kuwait}

In a sample of 88 pediatric vitiligo patients at a hospital dermatology clinic, the age of onset was between 8 and 12 years in $51 \%$ of these patients (Al-Mutairi et al., 2005). A positive family history was obtained in $27.3 \%$ of the patients. Vitiligo vulgaris was the most common clinical type observed. Three patients, though clinically asymptomatic, incidentally had antithyroid antibodies, which are comparable to results published previously.

Eighty Korean children (ages 8 months-12 years) with clinical and/or histopathologic diagnoses of vitiligo were evaluated; :39 boys and 41 girls. The mean age at first visit was 7.9 years and the mean age at disease onset was 5.6 years. The children were compared with a control group of 422 adults with vitiligo. Children comprised $16 \%$ of the total vitiligo patients and adults comprised 84\%. A family history of vitiligo was found in $11(13.8 \%)$ of 
children, compared to $10.7 \%$ in the adult group. ; pPoliosis was found in $20(25 \%)$ of children. $\mathrm{H}$; halo nevi was found in 2 (2.5\%) of children, compared to $4 \%$ in the adult group; combined autoimmune and endocrine diseases were noted in in 1 ( $1.3 \%$ of children), compared to $7.6 \%$ in the adult group; and segmental vitiligo in 26 (was diagnosed in $32.5 \%$ of children), compared to $13.0 \%$ inof the adult group. TheVitiligo and its associated conditions were combined diseases were significantly less often frequentfound in children compared tothan adults $(\mathrm{p}<0.01)$, and segmental vitiligo was found in significantly higher numbers of children than the adult patientsmore often associated with children $(p<0.0001)$. Thise study does id not show a higher prevalence of vitiligo in girls as reported in other studies, which may indicate a racial differencetrait (Cho et al., 2000).

\subsection{Indian subcontinent}

\subsubsection{India}

In India, the incidence of vitiligo was reported to be between 1- $2 \%$ (Majumder et al., 1988). In a large population-based study of vitiligo patients $(n=998), 43 \%$ were male $(n=429)$ and $(57 \%)$ were females $(n=569)$. The mean age at onset for males was found to be 23.3 years and for females was 17.4 years. The median age at onset in males was 18 years and 13.6 years in females. The earliest age at onset was found to be at birth and the oldest was 73 years (Tawade et al., 1997).Out of 998 cases, 272 (27.3\%) had one or more relatives with vitiligo. Among these, $207(76.1 \%)$ cases had only one relative affected whereas $65(28 \%)$ cases had more than one relative with vitiligo.

The slightly higher prevalence in females may not be the true situation, as only selfreported cases were enlisted in the study. Due to the social stigma of vitiligo in the community, young females tend to report earlier due to matrimonial anxiety. The age at onset is consistent with previous studies (Mosher et al., 1987). Onset at birth is not so common. In the present study 3 cases had onset of vitiligo at birth, of which One infant's mother had vitiligo. The peak incidence between 5-14 years may reflect concerns about cosmetic disfigurement in this age group and parental anxiety leading to early reporting. In another Indian study (Handa and Kaur, 1999), 1,436 patients were seen between 1989 and 1993. Males constituted $54.5 \%$ of the group and females, $45.5 \%$. Mean age of the patients was 25 years, and average disease duration at the time of hospital visit was 3.7 years. Leukotrichia was present in $165(11.5 \%)$, and Koebner's phenomenon was observed in 72 $(5.0 \%)$. Twenty-nine $(2 \%)$ patients had associated halo nevi. A family history of vitiligo was reported in 165 (11.5\%) patients.

A study was performed in a military service hospital patient population utilizing 120 cases of vitiligo (Kar, 2001). The youngest patient in this series was a 2 year-old girl and oldest patient was 65 year old male. In $52(43.2 \%)$ patients, disease started before the age of 20. The duration of disease varied from 2 months to ten years. Eight patients $(6.6 \%)$ reported a family history of vitiligo. In one case, a mother and her two daughters had vitiligo. The male -to -female ratio in vitiligo was observed in this study to be nearly equal, meaning thereby this disease had no predilection for any gender. Similar observations were also noted by various researchers (Sarin and Kumar, 1977; Behl et al., 1961). Furthermore, the incidence of vitiligo was $43.2 \%$ in the age group of 20 years of age and younger, as compared to an incidence of $9.9 \%$ in individuals over 40 years of age. Universal vitiligo was found in $2(1.6 \%)$ cases and both had a positive family history of disease. Other studies found a positive family history in $6.25-10 \%$ of cases (Sarin and 
Kumar, 1977; Behl et al., 1961). The results of this study may indicate that the mode of vitiligo transmission may be caused by an autosomal dominant gene with variable penetrance (Ando et al., 1993; Behl et al., 1994).

In an Indian pediatric population (Handa and Dogra, 2003), 625 children with vitiligo were seen over 10 years: $357(57.1 \%)$ were girls and 268 (42.9\%) were boys. As compared to adult patients with vitiligo, this sex difference was found to be statistically significant $(p<0.001)$. The mean age of onset of the disease was 6.2 years. Leukotrichia was present in 77 patients $(12.3 \%)$, while Koebner phenomenon was observed in 71 patients $(11.3 \%)$. Halo nevi were observed in 29 patients $(4.4 \%)$. Seventy-six patients $(12.2 \%)$ had a family history of vitiligo.

A total of 365 patients were included in a study that focused on the clinical and sociodemographic aspects of vitiligo. There was a female preponderance of disease: females $(68.4 \%)$ were found to be more affected than males $(31.6 \%)$, in a ratio of $2.1: 1$ (Shah et al., 2008). The majority (32.82\%) of the patients were in their second decade of life, and $58.63 \%$ of the patients were unmarried. A positive family history was present in $50(13.7 \%)$ of patients, and first-degree relatives were affected in 35 of these patients. Vitiligo has a polygenic or autosomal dominant inheritance pattern with incomplete penetrance and variable expression (Bleehen et al., 1992; Moscher et al., 1993; Bolognia and Pawelek, 1988). Familial occurrence has been reported to be in the range of $6.25 \%$ to $30 \%$ (Shajil et al., 2006). Positive family history is considered to be a poor prognostic factor for vitiligo.

The female-to-male ratio in this study was 2.1:1, which was different from other study findings (Handa and Kaur, 1999; Koranne et al., 1986). Most reports showed that males and females were affected with almost equal frequency, but females outnumbered males in this study presumably because of social stigma and the marital concerns which prompt women to seek early consultation. In $54.5 \%$ of the patients, the age at onset was in the first or second decade of life, consistent with most reports from India and the West.

\subsubsection{Mumbai}

In Mumbai, India, records of 33,252 new patients attending a dermatology outpatient department from June 2002 to June 2008 were analyzed for the presence of vitiligo (Poojary, 2011).

The total number of vitiligo patients was 204. The male: female proportion was almost equal. A family history of vitiligo was seen in 3.43\% of cases. Associated autoimmune disorders were seen in $2.94 \%$ of cases and were mainly skin associated autoimmune diseases (morphea, alopecia areata, discoid lupus erythematosus, and pemphigus erythematosus), except for one case of Grave's disease. This may indicate that the association of vitiligo with other autoimmune diseases emphasizes the autoimmune etiology of vitiligo, and also the need to actively look for, and if necessary, investigate patients with vitiligo for other autoimmune diseases.

\subsubsection{Calcutta}

An epidemiological profile of vitiligo in Calcutta was gathered from 15,685 individuals drawn from the general population; pedigree data was collected from 293 vitiligo patients. The overall prevalence of vitiligo was about 5 per 1,000 individuals. There were no significant sex or age differences. About a 4.5 -fold increase in prevalence was observed 
among close biological relatives of affected individuals. There were no significant differences in the frequencies of various types of vitiligo between probands with and without positive family history. The overall mean and modal ages of onset were about 22 years and 15 years, respectively. The mean ages among males (24.8 years) and females (19.3 years) were significantly different (Das et al., 1985).

\subsection{Africa}

\subsubsection{Tunisia}

In a retrospective study of patients attending a Tunisian outpatient dermatological practice (Zeglaoui et al., 1985), 503 patients were reviewed from a 5-year period. There were 288 women $(57.3 \%)$ and $215(42.7 \%)$ men ( $\mathrm{F}: \mathrm{M}=1.33)$. The average age was 28.2 years (3- 80 years). The peak of frequency was located in the second decade of the life (26\%). A family history of vitiligo was found in $27 \%$ of cases. The average time of until initial consultation was 21 months. An association with other pathological conditions was found in $23 \%$ of cases which is consistent with available literature.

\subsubsection{Nigeria}

To investigate vitiligo in the Nigerian Africans, 351 patients with vitiligo, representing $3.2 \%$ of new dermatologic cases at a study wsite, were enrolled (Onunu and Kubeyinje, 2003). The study group was made up of 153 males (43.6\%) and 198 females (56.4), giving a sex ratio of 1: 1.3. The peak incidence of vitiligo was in the second and third decades of life. There was a positive family history of vitiligo in $18 \%$ of subjects.

\subsection{Caribbean}

\subsubsection{French West Indies: Isle of Martinique}

A study was conducted in an academic dermatology clinic which analyzed a cohort of 2,077 dermatology outpatients. There was a vitiligo prevalence rate of $0.34 \%$, with a predominance of affected females. The median age at onset was 29 years. Of the vitiligo patients, over $30 \%$ had a family history of vitiligo, $6 \%(n=2)$ had concurrent thyroid disease, $6 \%(n=2)$ had psoriasis, and 3\% $(n=1)$ had atopic dermatitis. These findings are comparable to data in Caucasian populations (Boisseau-Garsaud et al., 2000).

\subsection{North America}

\subsubsection{United States}

Data on 160 Caucasian families living in the United States was collected based on primary probands with vitiligo (Majumder et al., 1993). The rate at which first degree relatives were also afflicted with vitiligo is $20 \%$. Children of probands were found to have 1.7 times the risk of vitiligo compared to other first-degree relatives. The relative risk (RR) for vitiligo was approximately 7 for parents, 12 for siblings, and 36 for children. For second-degree relatives, the RR varied between 1 and 16. The pattern of the relationship between RR and degree of kinship indicates the involvement of genetic factors, although it is not consistent with singlelocus Mendelian transmission.

In general, patients with vitiligo who have an family history of vitiligo are more likely to have an earlier age of onset of disease than those with a negative family history (odds ratio $=3.70, P=.024)$. There was found to be no association between family history and site of onset, distribution, or course of disease. Onset of pediatric vitiligo also seemed to 
be linked to a family history of vitiligo. This suggests that awareness of this association can allow for earlier detection and initiation of treatment (Pajvani et al., 2006).

\section{Genetic heritability of vitiligo}

\subsection{Familial aggregation of vitiligo and relationship with autoimmune diseases}

Familial aggregation of vitiligo was noted as early as 1933 (Majumder, 2000), suggesting that genetic factors might have an important effect on the development of vitiligo (Hafez et al., 1983). Although vitiligo aggregates in families, it does not appear to segregate in a simple Mendelian pattern (Majumder et al., 1993; Kim et al., 1997; Nordlund and Majumder, 1997). Previously, an autosomal recessive model of vitiligo that took the variability of the age of onset into account was proposed, suggesting that there might be genes at three or four autosomal loci controlling vitiligo (Alkhateeb et al., 2002; Majumder et al., 1988). This was supported by the high frequency of vitiligo and other autoimmune diseases in isolated inbred communities. On the other hand, the actual onset of vitiligo in genetically susceptible individuals seems to require exposure to environmental triggers (Nath et al., 1994; Birela et al., 2008). Attempts to identify genes involved in vitiligo susceptibility have involved gene expression studies, allelic association studies of candidate genes, and genome-wide linkage analyses to discover new genes (Zhang et al., 2008).

Most evidence indicates that generalized vitiligo is an organ-specific autoimmune disease directed against melanocytes (Ongenae et al., 2003; Rezaei et al., 2007), and indeed about $20 \%$ of vitiligo patients (and their close relatives) manifest concomitant occurrence of other autoimmune diseases, particularly autoimmune thyroid disease, rheumatoid arthritis, lateonset type I diabetes mellitus, psoriasis, pernicious anemia, systemic lupus erythematosus, and Addison's disease (Alkhateeb et al., 2003 ). Nevertheless, heritable biological properties of the melanocyte or other factors, combined with environmental triggers, may contribute to loss of immune tolerance and ultimately autoimmunity directed against melanocytes (Boissy and Spritz, 2009). Family clusters of vitiligo cases are not uncommon, occurring in a non-Mendelian pattern suggestive of polygenic, multifactorial inheritance. Probands' firstdegree relatives have 6-7\% risk of developing generalized vitiligo, and the concordance rate in monozygotic twins is $23 \%$.

Genetic linkage and association studies have implicated a number of genes in vitiligo pathogenesis, especially genes involved in immune function (Spritz, 2007; Spritz, 2008). However, these loci account for a relatively small fraction of total disease liability. Genetically isolated "founder populations" afford special opportunities to identify genes involved in susceptibility to disease, as founder populations may have elevated prevalence of specific diseases and reduced heterogeneity of causal genetic and environmental risk factors compared with more outbred populations (Wright et al., 1999). Accordingly, susceptibility alleles that represent relatively minor genetic risk factors for complex diseases in the general population may become amplified and constitute major risk alleles in a founder population, and thus may be localized using less dense maps and smaller sample sizes than similar studies conducted in more outbred populations (Wittke-Thompson et al., 2007).

\subsection{Genetic basis of vitiligo}

Genes play a role in all aspects of vitiligo pathogenesis, even in response to environmental triggers. Typical generalized vitiligo behaves as a "complex trait", meaning it is a polygenic, multifactorial disease involving multiple genes and non-genetic factors. Only a few vitiligo 
susceptibility genes have been identified with reasonable certainty. These include human leukocyte antigen (HLA), protein tyrosine phosphatase, non-receptor type 22 (PTPN22), and, NACHT, LRR and PYD domains-containing protein 1 (NALP1), all genes associated with autoimmune susceptibility. Cytotoxic lymphocyte antigen 4 (CTLA4) is also under investigation (Spitz, 2008).

The earliest evidence suggesting a genetic basis for vitiligo was its association with a number of other autoimmune disorders known to have heritable predispositions, such as type 1 diabetes mellitus. Furthermore, genetic diseases are substantially more prevalent in children of parents who are close relatives. In an Indian study of a community with a predominance of consanguineous marriages, $20 \%$ of individuals had vitiligo (Ramaiah et al., 1988). Significantly earlier onset has been observed when there is a family history of vitiligo (24.8 vs. 42.2 years of age) (Hann and Lee, 1996).

Genetic models suggested by analysis of family studies include a multifactorial model (Goudie et al., 1983), a dominant model with incomplete penetration (Hafez et al., 1983), and a multilocular recessive model (Majumder et al., 1988). There may also be two coexisting modes of inheritance for vitiligo depending on age of onset (Arcos-Burgos et al., 2002). In patients with early onset vitiligo (before the age of 30), vitiligo inheritance most closely follows a dominant mode of inheritance with incomplete penetration. However, a predisposition for vitiligo resulting from a recessive genotype and exposure to certain environmental triggers appears to explain the inheritance pattern of late onset vitiligo (after 30 years of age). Specific HLA haplotypes are strongly associated with family history of vitiligo, severity of disease, age of onset, and population geography (Zamani et al., 2001; Ando et al., 1993; Finco et al., 1991). Gene polymorphisms in the major histocompatibility complex (MHC) Class II region of the HLA locus have been previously found to be associated with other autoimmune diseases, such as type 1 diabetes mellitus and juvenileonset rheumatoid arthritis (Deng et al., 1995; Prahalad et al., 2001). The HLA genes encoding both the transporter associated with antigen-processing (TAP1) and subunits of the immunoproteasome latent membrane protein 2 and 7 (LMP2/LMP7) have been found to be associated with vitiligo of early onset in Caucasian patients (Casp et al., 2003).

The (CTLA-4) gene encodes a protein involved in the inhibition of improperly-activated Tcells. CTLA-4 variants have been linked to numerous autoimmune diseases. There is an association between the CTLA-4 polymorphism and the occurrence of vitiligo with other autoimmune comorbidities (Blomhoff et al., 2005). Catechol-O-methyl transferase (CTLA-4) is an enzyme that plays a major role in the metabolism of toxic or biologically active drugs, neurotransmitters and metabolites. One such metabolite, O-quinones, can be formed during melanin synthesis in the absence of adequate CTLA-4 activity. A CTLA-4 polymorphism has been found to be significantly associated with acrofacial vitiligo (Tursen et al., 2002).

Chromosome 1p31, termed the autoimmune susceptibility locus (AIS1), has been found to be associated to a highly significant degree with generalized vitiligo in Caucasians living in North American and the United Kingdom (Fain et al., 2003). Reduced activity of the VIT1 gene, located on chromosome $2 \mathrm{p} 16$, has been associated with increased susceptibility to vitiligo, possibly as a result of dysfunction of melanocyte nucleotide mismatch repair(Lee Poole, 2001).

A genome-wide association study of generalized vitiligo in an isolated European founder population identified a significant association of single-nucleotide polymorphisms in a block on band $6 \mathrm{q} 27$, in close vicinity to IDDM8, which is a linkage and an association signal for type I diabetes mellitus and rheumatoid arthritis. Only one gene, SMOC2, is in the region of 
association, within which single-nucleotide polymorphism (SNP) rs13208776 attained genome-wide significance for association with other autoimmune diseases and vitiligo (Birlea et al., 2009).

Genetic risk for vitiligo is well-supported by multiple lines of evidence. Vitiligo is frequently associated with familial clustering (Alkhateeb et al., 2003; Goudie et al., 1983; Mehta et al., 1973; Carnevale et al., 1980). Approximately $20 \%$ of probands have at least one affected first degree relative. The risk of first degree relatives of patients with vitiligo for developing the disease is elevated by 7 - to 10 -fold compared to the general population (Alkhateeb et al., 2003; Sun et al. 2006).

In addition, segregation analysis suggests that vitiligo is a multifactorial and polygenic disorder that likely results from multiple genetic and environmental factors (Alkhateeb et al., 2003; Arcos-Burgos et al., 2002; Nath et al., 2001; Spritz et al., 2004). However, no disease genes have been identified for vitiligo thus far. Several genome-wide linkage analyses of vitiligo have been performed in the past few years, and multiple linkages to vitiligo have been identified (Alkhateeb et al., 2002; Fain et al., 2003; Spritz et al., 2004). Co-segregation of systemic lupus erythematosus and vitiligo in European American pedigrees revealed significant linkage on 17p13 (Nath et al., 2001). Another co-segregation of vitiligo and Hashimoto thyroiditis identified a candidate gene with highly significant linkage at a locus ( "AIS1") on chromosome 1p32.2-p31.3 (Alkhateeb et al., 2002; Spritz et al., 2004), as well as additional linkage evidence on chromosomes 1, 7, 8, 11, 19, and 22 (Spritz et al., 2004). There are confirmed linkage findings on chromosomes $7 \mathrm{q}$ and $8 \mathrm{p}$ (AIS2 and AIS3) (Nath et al., 2001). The linkage evidence at the AIS1, AIS2, and systemic lupus erythematosus, vitiligorelated 1 (SLEV1) loci was mainly from autoimmunity-associated families, while the evidence at the AIS3 locus was primarily from non-autoimmunity-associated families, suggesting that generalized vitiligo may be divided into two distinct phenotypic subcategories that involve different disease loci or alleles.

\section{Conclusion}

Vitiligo is a common, acquired, discoloration of the skin. Most studies show that vitiligo is common in the younger age group, with females of reproductive age forming the major group. Genetic factors play a relatively important role in the evolution of vitiligo. The extent of familial aggregation of vitiligo is statistically significant. The genetic model of vitiligo may be consistent with a polygenetic or multifactorial inheritance in a dominant gene pattern.

\section{References}

Agarwal G. Vitiligo: An under-estimated problem. Fam Pract 1998;15:519-23.

Akay BN, Bozkir M, Anadolu Y, Gullu S. Epidemiology of vitiligo, associated autoimmune diseases and audiological abnormalities: Ankara study of 80 patients in Turkey. J Eur Acad Dermatol venereal. 2010 Oct;24(10):1144-50.

Alkhateeb A, Fain PR, Thody A, Bennett DC, Spritz RA. Epidemiology of vitiligo and associated autoimmune diseases in Caucasian probands and their families. Pigment Cell Res 2003;16:208-14. 
Alkhateeb A, Stetler GL, Old W, Talbert J, Uhlhorn C, Taylor M, et al. Mapping of an autoimmunity susceptibility locus (AIS1) to chromosome 1p31.3-p32.2. Hum Mol Genet. 2002; 11:661-7.

Al-mutairi N, Sharma AK, Al-Sheltawy M, Nour-Eldin O. Childhood vitiligo: a prospective hospital-based study. Australas J. 2005 Aug;46(3):150-3.

Alzolibani A. Genetic epidemiology and heritability of vitiligo in the Qassim region of Saudi Arabia. Acta Dermatovenerol Alp Panonica Adriat. 2009 Sep;18(3):119-25.

Ando-I, Chi-HI, Nakagawa H, et al. Differences in clinical features and HLA antigens between familial and non familial vitiligo of non segmental type. Br J Dermatol 1993; 123:408-410.

Arakawa A. Quoted by Robert P. Uber die Vitiligo, Dermatologica 1941;84:257-319.

Arcos-Burgos M. Parodi E. Salgar M. Bedoya E. Builes J. Jaramillo D. Ceballos G. Uribe A. Rivera N. Rivera D. Fonseca I. Camargo M. Palacio G. Vitiligo: complex segregation and linkage disequilibrium analyses with respect to microsatellite loci spanning the HLA. Hum Genet 2002; 110: 334-42.

Arycan O, Koc K, Ersoy L. Clinical characteristics in 113 Turkish vitiligo patients. Acta dermatovenerol Alp Panonica Adriat. 2008 Sep; 17(3):129-32.

Behl PN, Agarwal RS, Singh G. Etiological studies in vitiligo and therapeutic response to standard treatment. Indian J Dermatol 1961;6:101.

Behl PN, Aggarwal A, Srivastava G. Vitiligo In : Behl PN, Srivastava G, editors. Practice of Dermatology. 9 th ed. CBS Publishers: New Delhi; 2003. p. 238-41.

Behl PN, Bhatia RK. 400 case of vitiligo - A clinico therapeutic analysis. Indian J Dermatol 1971;17:51-4.

Behl PN, Kotia A, Sawal P. Vitiligo: Age group related trigger factor and morphological variants. Indian J Dermatol Venereol Lepr 1994;60: 275-279.

Birlea SA, Fain PR, Spritz RA. A Romanian population isolate with high frequency of vitiligo and associated autoimmune diseases. Arch Dermatol. 2008 Mar;144(3):310-6.

Birlea SA, Gowan K, Fain PR, Spritz RA. Genome-Wide Association Study of Generalized Vitiligo in an Isolated European Founder Population Identifies SMOC2, in Close Proximity to IDDM8. J Invest Dermatol. Nov 52009.

Bleehen SS, Ebling FJ, Champion RH. Disorders of skin color. In : Champion RH, Burton JL, Ebling FJ, editors. Text book of Dermatology. London: Blackwell Scientific Publications; 1992. p. 1561-622.

Blomhoff A. Helen Kemp E. Gawkrodger DJ. Weetman AP. Husebye ES. Akselsen HE. Lie BA. Undlien DE. CTLA4 polymorphisms. Pigment Cell Res 2005; 18: 55-8.

Boisseau-Garsaud AM, Garsaud P, Cales-Quist D, Helenon R, Queneherve C, Clair RC. Epidemiology of vitiligo in the French West Indies (Isle of Martinique). Int J Dermatol. 2000 Jan;39(1):18-20.

Boissy RE, Spritz RA (2009) Frontiers and controversies in the pathobiology of vitiligo: separating the wheat from the chaff. Exp Dermatol 18:583-5

Bolognia JL, Nordlund JJ, Ortonne J-P (1998) Vitiligo vulgaris.In: Nordlund JJ, Boissy RE, Hearing VJ, King RA, Ortonne J-P (eds) The pigmentary system. Oxford UniversityPress, New York, pp 513-551.

Bolognia JL, Pawelek JM. Biology of hypopigmentation. J Am Acad Dermatol 1988;19:21755. 
Canizares O. Geographic dermatology: Mexico and Central America. Arch Dermatol 1960; 82: 870-93.

Carnevale A, Zavala C, Castillo VD, Maldonado RR, Tamayo L (1980) Analisis genetico de 127 families con vitiligo. Rev Invest Clin 32:37-41.

Casp CB. She JX. McCormack WT. Genes of the LMP/TAP cluster are associated with the human autoimmune disease vitiligo. Genes Immun 2003; 4: 492-9.

Cho S, Kang KC, Hahm JH. Characteristics of vitiligo in Korean children. Pediatr Dermatol 2000;17:189-93.

Das SK, Majumder PP, Chakraborty R, Majumdar TK, Haldar B. Studies on vitiligo. I. Epidemiological profile in Calcutta, India. Genet Epidemiol. 1985; 2(1):71-8.

Dawber RP. Vitiligo in Mature onset diabetes mellitus. Br J Dermatol 1968;80:275-8.

Deng GY. Muir A. Maclaren NK. She JX. Association of LMP2 and LMP7 genes within the major histocompatibility complex with insulin-dependent diabetes mellitus: population and family studies. Am J Hum Gen 1995; 56: 528-34.

El Mofty AM. Vitiligo and psoralens. Pergamon Press: Oxford; 1968. p. 1147-95.

El-Hazmi MA, Al-Swailem A R, Warsy A S, Al-Swailem A M, Sulaimani R, Al-Meshari A A. Consanguinity among the Saudi Arabian population. J Med Genet. 1995 August; 32(8): 623-6.

Engel L. What are those white patches in my patient's skin? Dermatol Nurs 2001;13:292-7.

Fain PR, Gowan K. LaBerge GS. Alkhateeb A. Stetler GL. Talbert J. Bennett DC. Spritz RA. A genome-wide screen for generalized vitiligo: confirmation of AIS1 on chromosome 1 p31 and evidence for additional susceptibility loci. Am J Hum Gen 2003; 72: 1560-4.

Finco OM, Cuccia M, Martinetti G, Ruberto G, Orecchia G, Rabbiosi G. Age of onset in vitiligo: relationship with HLA supratypes. Clin Genet 1991; 39: 48-54.

Fitzpatrick TB. Phototherapy of vitiligo, in sunlight and man. Normal and abnormal biologic response. In : Pathak MA, editor. University of Tokyo Press: Tokyo; 1974. p. 783-91.

Fornara I. Quoted by Robert P. Uber die vitiligo. Dermatologica 1941;4:241-319.

Gauthier Y, Cario-Andre M, Lepreux S, Pain C, Taieb A. Melanocyte detachment after skin friction in non lesional skin of patients with generalized vitiligo. Br J Dermatol 2003;148:95-101.

Goudie BM, Wilkieson C, Goudie RB. A family study of vitiligo patterns. Scott Med J 1983; 28: 338-42.

Goudie BM, Wilkieson C, Goudie RB. Skin maps in vitiligo. Scott Med J 1983;28:343-6.

Grunnet I, Howitz J, Reymann F, Schwartz M. Vitiligo and pernicious anemia. Arch Dermatol 1970;101:82-5.

Hafez M, Sharaf L, El-Nabi SMA. The genetics of vitiligo. Acta Derm Venereol. 1983;63:249-51.

Halder R, Taliaferro S. Vitiligo. In: Wolff K, Goldsmith L, Katz S, Gilchrest B, Paller A, Lefell D, eds. Fitzpatrick's Dermatology in General Medicine. Vol 1. $7^{\text {th }}$ ed. New York, NY: McGraw-Hill; 2008:72.

Halder RM. Childhood Vitiligo. Clin Dermatol 1997;15:899-906.

Handa S, Dogra S. Epidemiology of childhood vitiligo: A study of 625 patients from North India. Pediatr Dermatol 2003;20:207-10.

Handa S, Kaur I. Vitiligo - Clinical findings in 1436 patients. J Dermatol Tokyo 1999; 26: 653-7.

Hann SK, Lee HJ. Segmental vitiligo, clinical findings in 208 patients. J Am Acad Dermatol 1996;35:671-4. 
Hann SK, Lee HJ. Segmental vitiligo: clinical findings in 208 patients. J Am Acad Dermatol 1996;35: 671-4.

Hann S-K, Nordlund J (2000) Vitiligo: a comprehensive monograph on basic and clinical science. Blackwell Science, Oxford, United Kingdom.

Hann SK, Park YK, Chun WH. Clinical feature of vitiligo. Clin Dermatol 1997;15:891-7.

Howitz J, Brodthagen H, Schwartz M, Thomsen K. Prevalence of vitiligo: Epidemiological survey the Isle of Bornholm, Denmark. Arch Dermatol 1977; 113: 47-52.

Jaigirdar MQ, Alam SM, Maidul AZ. Clinical presentation of vitiligo. Mymensingh Med J 2002;11:79-81.

Jeninger CK. Childhood vitiligo. Br J Dermatol 1993;51:25-8.

Kar PK. Vitiligo: A study of 120 cases. Indian J Dermatol Venereol Leprol 2001;67:302-4.

Khoo OT. Vitiligo. A review and report of treatment of 60 cases in the general hospital, Singapore, from 1954 to 1958. Singapore Med J 1962;3:157-68.

Kim SM, Chung HS, Hann SK. The genetics of vitiligo in Korean patients. Int J Dermatol. 1997;37:908-10.

Koranne RK, Sachdeva KG. Vitiligo. Int J Dermatol 1988;27:676-81.

Koranne RV, Sehgal VN, Sachdeva KG. Clinical profile of vitiligo in North India. Indian J Dermatol Venereol Leprol 1986;52:81-2.

Kovacs SO. Vitiligo. J Am Acad Dermatol 1998;38:647-66.

Le Poole C, Boissy RE. Vitiligo. Semin Cutan Med Surg 1997;16:3-14.

Le Poole IC. Sarangarajan R. Zhao Y. Stennett LS. Brown TL. Sheth P. Miki T. Boissy RE. VIT1, a novel gene associated with vitiligo. Pigment Cell Res 2001; 14: 475-84.

Lerner AB. Vitiligo. J Invest Dermatol 1959;32:285-310.

Lerner MR, Fitzpatrick TB, Halder RM, Hawk JL. Discussion of a case of vitiligo. Photodermatol Photoimmunol Photomed 1999;15:41-4.

Levai M. A study of certain contributory factors in the development of vitiligo in South Indian patients. AMA Arch Derm 1958;78:364-71.

Majumder PP, Das SK, Li CC. A genetical model for vitiligo. Am J Hum Genet. 1988;43:11925.

Majumder PP, Nordlund JJ, Nath SK. Pattern of familial aggregation of vitiligo. Arch Dermatol 1993; 129: 994-8.

Majumder PP. Genetics and prevalence of vitiligo vulgaris. In: Hann SK, Nordlund JJ, editors. Vitiligo. Oxford: Blackwell Science; 2000. p. 18-20.

Mason CP and Gawk Rodger DJ (2005) Vitiligo presentation in adults. Clin Exp Dermatol. 2005 Jul; 30(4):344-5.

Mehta NR, Shah KC, Theodore C, Vyas VP, Patel AB (1973) Epidemiological study of vitiligo in Surat area. Indian J Med Res 61:145-154.

Moscher DB, Fitzpatrick TB, Hori Y, Ortonne JP. Disorders of pigmentation. In : Fitzpatick TB, Isen AZ, Wolff K, Freedberg IM, Austen KF, editors. Dermatology in general medicine. New York: McGraw Hill; 1993. p. 903.

Mosher DB, Fitzpatrick TB, Ortanne JB. Disorders of pigmentation, hypomelanoses and hypermelanoses, In: Freedberg IM, Eisen AZ, Fitzpatrick TB, editors. Dermatology in general medicine. 5th ed. New York: McGraw-Hill; 1999. p. 936-45.

Mosher DM, Fitzpatrick TB, et al. Disorders of pigmentation. In: Fitzpatrick TB, Eisen AZ, Wolft K, et al, editors. Dermatology in general medicine. New York: McGraw Hill Company, 1987;810-21. 
Nath SK, Kelly JA, Namjou B, Lam T, Bruner GR, Scofield RH, Aston CE, Harley JB (2001) Evidence for a susceptibility gene, SLEV1, on chromosome 17p13 in families with vitiligo-related systemic lupus erythematosus. Am J Hum Genet 69:1401-1406.

Nath SK, Majumder PP, Nordlund JJ. Genetic epidemiology of vitiligo: multilocus recessivity cross-validated. Am J Hum Genet. 1994;55:981-90.

Njoo MD, Westerhof W. Vitiligo: Pathogenesis and treatment. AmJ Clin Dermatol 2001;2:167-181.

Nordlund JJ, Lerner AB. Vitiligo-it is important. Arch Dermatol 1982;118:5-8.

Nordlund JJ, Majumder PP. Recent investigations in vitiligo vulgaris. Dermatol Clin. 1997;15:69-78.

Ongenae K, Van Geel N, Naeyaert JM (2003) Evidence for an autoimmune pathogenesis of vitiligo. Pigment Cell Res 16:90-100

Onunu AN, Kubeyinje EP. Vitiligo in the Nigerian African: a study of 351 patients in Benin City, Nigeria. Int J Dermatol. 2003 Oct; 42(10):800-2.

Pajvani U, Ahmad N, Wiley A, Levy RM, Kundu R, Mancini AJ, Chamlin S, Wagner A, Paller AS. The relationship between family medical history and childhood vitiligo. J Am Acad Dermatol. 2006 Aug; 55(2):238-44.

Panja G. Leukoderma. Indian J Vener Dis 1947;13:56-63.

Perrot H. Vitiligo, Thyreopallisis et autominunization. Lyon. Med 1973;30:325-31.

Poojary SA. Vitiligo and associated autoimmune disorders: A retrospective hospital-based study in Mumbai, India. Allergol Immunopathol (madr) 2011 Apr 5. [Epub ahead of print].

Prahalad S. Kingsbury DJ. Griffin TA. Cooper BL. Glass DN. Maksymowych WP. Colbert RA. Polymorphism in the MHC- encoded LMP7 gene: association with JRA without functional significance for immunoproteasome assembly. J Rheumatol 2001; 28: 2320-5.

Punshi SK, Thakre RD. Skin survey. Maharashtra Med J 1969;16: 535-6.

Ramaiah A, Mojamdar MV, Amarnath VM. Vitiligo in the SSK community of Bangalore. Indian JDermatol Veneroel Lepr 1988; 54: 251-4.

Rezaei N, Gavalas NG, Weetman AP et al. (2007) Autoimmunity as an aetiological factor in vitiligo. J Eur Acad Dermatol Venereol 21:865-76.

Ruiz-Maldonado R, Tamayo Sanchez L, Velazquez E. Epidemiology of skin diseases in 10,000 patients of pediatric age. Bol Med Hosp Infant Max 1977;34:137-61.

Sarin RC, Kumar AS. A clinical study of vitiligo. Indian J Dermatol Venereol Lepr 1977;83:190-194.

Sehgal VN. A clinical evaluation of 202 cases of Vitiligo. Cutis 1974;14:439-45.

Shah H, Mehta A, Astik B. Clinical and sociodemographic study of vitiligo. Indian J Dermatol Venereol Leprol 2008;74:701.

Shajil EM, Agrawal D, Vagadia K, Marfatia YS, Begum R. Vitiligo: Clinical profiles in Vadodara, Gujarat. Indian J Dermatol 2006;51:100-4.

Shwartz RA, Janniger CK. Vitiligo. Cutis 1997;60:239-44.

Singh M, Singh G, Kanwar AJ, Belhaj MS. Clinical pattern of vitiligo in Libya. Int J Dermatol. 1985;24:233-5.

Spritz RA (2007). The genetics of generalized vitiligo and associated autoimmune diseases. Pigment Cell Res 20:271-8

Spritz RA (2008) The genetics of generalized vitiligo. Curr Dir Autoimmun 10:244-57. 
Spritz RA, Gowan K, Bennett DC, Fain PR (2004) Novel vitiligo susceptibility loci on chromosomes 7 (AIS2) and 8 (AIS3), confirmation of SLEV1 on chromosome 17, andtheir roles in an autoimmune diathesis. Am J Hum Genet 74:188-191.

Srivastava G. Vitiligo- Introduction Asian Clinic. Dermatol 1994;1:1-5.

Sun X, Xu A, Wei X, Ouyang J, Lu L, Chen M, Zhang D. Genetic epidemiology of vitiligo: a study of 815 probands and their families from south China. Int J Dermatol. 2006 Oct;45(10):1176-81.

Tawade YV, Parakh AP, Bharatia PR, Gokhale BB, Ran. Vitiligo : a study of 998 cases attending KEM Hospital in Pune. Indian J Dermatol Venereol Leprol 1997;63:95-8.

Tursen U. Kaya TI. Erdal ME. Derici E. Gunduz O. Ikizoglu G. Association between catechol-Omethyltransferase polymorphism and vitiligo. Arch Dermatol Res 2002; 294: 143-6.

Westerhof W, Bolhaar B, Menke HE, et al. Resultaten van een enquete onder vitiligo patienten. Ned Tjdschr Dermatol Venereol 1996;6:100-105.

Westerhof W. Vitiligo-a window in the darkness. Dermatology 1995;190:181-2.

Wittke-Thompson JK, Ambrose N, Yairi E et al. (2007) Genetic studies of stuttering in a founder population. J Fluency Disord 32:33-50

Wright AF, Carothers AD, Pirastu M (1999) Population choice in mapping genes for complex diseases. Nat Genet 23:397-404

Xu YY, Ye DQ, Tong ZC, Hao JH, Jin J, Shen SF, Li CR, Zhang XJ (2002) An epidemiological survey for four skin diseases in Anhui [In Chinese]. Chin J Dermatol 35:406-407.

Zaima H, Koga M. Clinical course of 44 cases of localized type vitiligo. J Dermatol 2002;29:15-9.

Zamani M, Spaepen M, Sghar SS, Huang C, Westerhof W, Nieuweboer-Krobotova L, Cassiman JJ. Linkage and association of HLA class II genes with vitiligo in a Dutch population. Br J Dermatol 2001; 145: 90-4.

Zeglaoui F, Souissi A, Ben Ayed A, Fazaa B, Kamoun MR. Epidemiological and clinical profile of vitiligo in Tunisia: retrospective study of 503 cases. Tunis Med. Dec; 85(12):1016-9.

Zhang XJ. Clinical profiles of vitiligo in China: an analysis of 3742 patients. Clin Exp Dermatol. 2005;30:327-31.

Zhang Z, Xu SX, Zhang FY, Yin XY, Yang S, Xiao FL, et al. The analysis of genetics and associated autoimmune diseases in Chinese vitiligo patients. Arch Dermatol Res. 2008 Oct 7. 


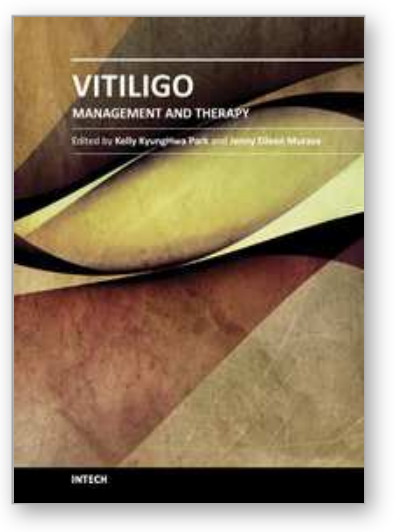

\author{
Vitiligo - Management and Therapy \\ Edited by Dr. Kelly KyungHwa Park
}

ISBN 978-953-307-731-4

Hard cover, 174 pages

Publisher InTech

Published online 14, December, 2011

Published in print edition December, 2011

Vitiligo: Management and Therapy is a practical guide to vitiligo that reflects current research related to the fundamentals of vitiligo and its management. Vitiligo experts and researchers from all over the world have contributed to this text, accounting for its comprehensive nature and diverse array of topics. The recent advances in medicine and technology have led to a better understanding of the disease and have broadened available treatment options. The essentials are captured in this book and are complemented by useful clinical photographs and reference tables. This concise tool will serve as an invaluable resource for clinicians in daily practice.

\title{
How to reference
}

In order to correctly reference this scholarly work, feel free to copy and paste the following:

Abdullateef A. Alzolibani, Ahmad Al Robaee and Khaled Zedan (2011). Genetic Epidemiology and Heritability of Vitiligo, Vitiligo - Management and Therapy, Dr. Kelly KyungHwa Park (Ed.), ISBN: 978-953-307-731-4, InTech, Available from: http://www.intechopen.com/books/vitiligo-management-and-therapy/geneticepidemiology-and-heritability-of-vitiligo

\section{INTECH}

open science | open minds

\section{InTech Europe}

University Campus STeP Ri

Slavka Krautzeka 83/A

51000 Rijeka, Croatia

Phone: +385 (51) 770447

Fax: +385 (51) 686166

www.intechopen.com

\section{InTech China}

Unit 405, Office Block, Hotel Equatorial Shanghai

No.65, Yan An Road (West), Shanghai, 200040, China

中国上海市延安西路65号上海国际贵都大饭店办公楼405单元

Phone: +86-21-62489820

Fax: +86-21-62489821 
(C) 2011 The Author(s). Licensee IntechOpen. This is an open access article distributed under the terms of the Creative Commons Attribution 3.0 License, which permits unrestricted use, distribution, and reproduction in any medium, provided the original work is properly cited. 